\title{
Hepatoblastoma with Pure Fetal Epithelial Differentiation
}

National Cancer Institute

\section{Source}

National Cancer Institute. Hepatoblastoma with Pure Fetal Epithelial Differentiation. NCI

Thesaurus. Code C7093.

A hepatoblastoma composed of small cells resembling the fetal hepatocytes, forming thin trabeculae. 